\title{
Spectrophotometric Determination of Nitrazepam by Coupling of Diazotized Reduced Nitrazepam with N-(1-naphthyl)ethyl- enediamine Dihydrochloride
}

\author{
Yousra M. Al-Shaker \\ Department of Environmental \\ College of Environment \\ University of Mosul
}

\author{
Imad Y. Hasan \\ Department of Chemistry \\ College of Science \\ University of Mosul
}

(Received 6/2/2011; Accepted 6/6/2011)

\begin{abstract}
A simple, rapid, accurate and precise spectrophotometric method is proposed for the determination of nitrazepam in pure form. The method is based on the reduction of nitrazepam by zinc powder in concentrated hydrochloric acid medium followed by diazotization of reduced nitrazepam and coupling with $\mathrm{N}$-(1-naphthyl)ethylenediamine dihydrochloride (NEDA) to give a pink coloured product which is stable, water-soluble and has a maximum absorption at $564 \mathrm{~nm}$ with a molar absorptivity of $1.633 \times 10^{3} 1 . \mathrm{mol}^{-1} . \mathrm{cm}^{-1}$. Beer's law is obeyed in the concentration range of 10 to $500 \mu \mathrm{g}$ of nitrazepam in a final volume of $25 \mathrm{ml}$.

\section{القدير اللمي للنليترازببلم بفالل الفترل الآزوت النليترازببلم المختزل مع الكلثف

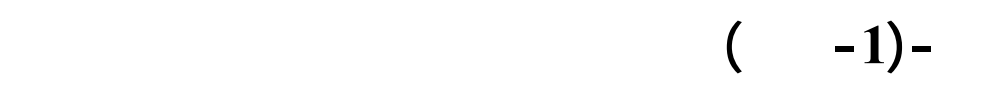

\section{الملغص}

مق اقتراحطريقةطيفية بسيطة،سريعة، دقيقة ومتوافقة لقدير النايترازيبلم بـ شكله الق مي اعتم دت

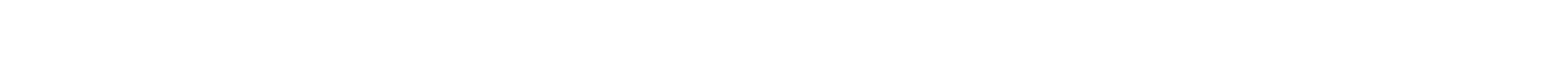

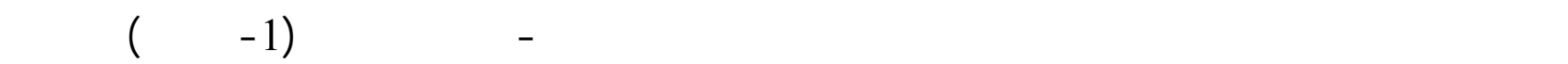

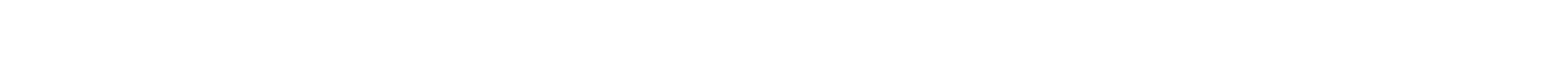

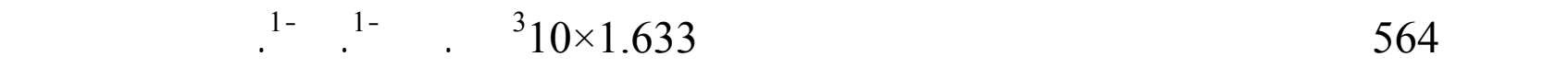
بير في مدى التركيز بين 10 و500 مايكروغرالم من النايترازيبلم في حهم نهائي 25 مللتر.
\end{abstract}




\section{INTRODUCTION}

Six benzodiazepines play prominent roles in the therapy of epilepsy. Although benzodiazepines are chemically quite similar with a suitable structural, there are differences in their activities. They have two different mechanisms of antiseizure action. Nitrazepam is used for infantile spasms and myoclonic seizures (Katzung, 1998). Nitrazepam is 7-nitro-5phenyl-1,3-dihydro-2H-1,4-benzodiazepin-2-one (British pharmacopeia, 2000).

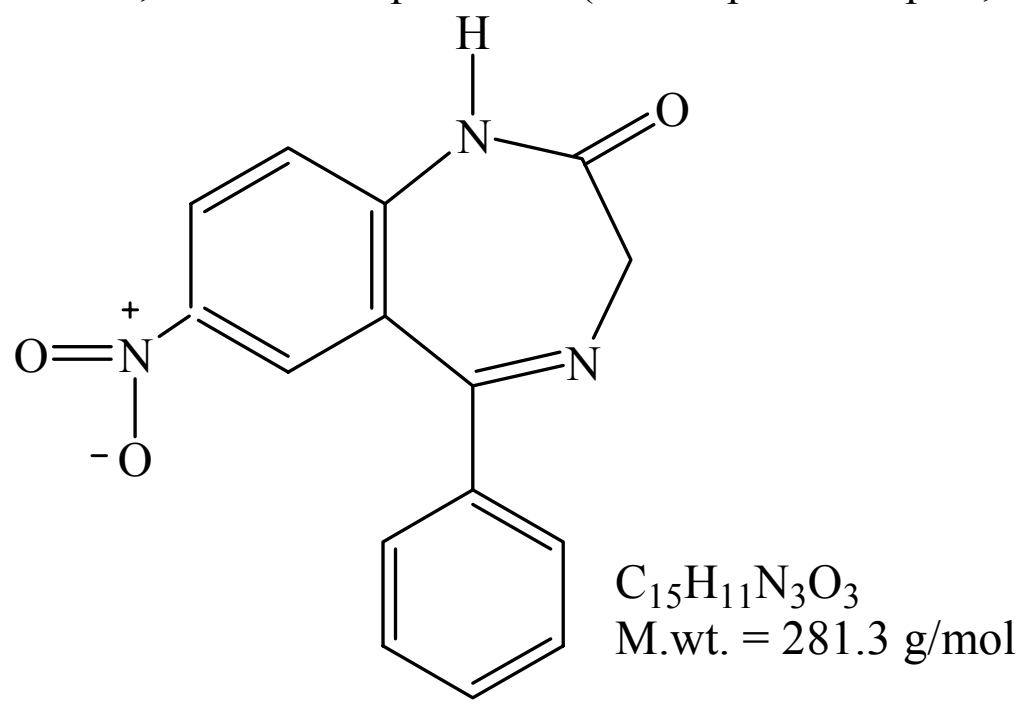

Nitrazepam is a yellow, crystalline powder and it is classified to benzodiazepines group. Many analytical methods are used for its determination such as a spectrophotometric methods. These include reduction of nitrazepam with other 1,4- benzodiazepines compounds by using $\mathrm{Zn} / \mathrm{HCl}$ and measuring the difference in their absorbance before and after reduction (Elbrashy, 1993). Another spectrophotometric method was described for the determination nitrazepam in the drug dosage forms (Davidson, 2005). Another colorimetric method is also described for the determination of nitrazepam by its reaction with tertabutylammonium hydroxide in dimethylformamide to form an orange colour (Walash, 1993). A kinetic method for the determination of nitrazepam by the continuous addition of reagent (CAR) technique is reported. The method involves the formation of an azo dye between 1-naphthol and a diazonium salt in turn obtained by reaction between the drug and nitrous acid. The absorbance of the azo dye is measured at $600 \mathrm{~nm}$ (Carmona, 1992). A method involving high performance liquid chromatography with dual electrode electrochemical detection in there doxmode (LC-DED) has been developed for the determination of nitrazepam benzodiazepine and tranquilizer in serum (Honeychurch, 2006). Also, HPLC technique is used to separate and determine fifteen benzodiazepines in human blood (Yokchue, 2010). Direct quantitative densitometry of nitrazepam and its main metabolites in urine is developed. These compounds are separated by thin-layer chromatography (Inoue, 1985). 


\section{EXPERIMENTAL}

\section{Instruments}

All spectrophotometric measurements are performed on Shimadzu UV-160A, UVVisible recording spectropho-tometer.

\section{Reagents}

All chemicals used are of analytical reagent grade.

\section{Standard reduced form of nitrazepam solution, $100 \mu \mathrm{g} \cdot \mathrm{ml}^{-1}$.}

This solution is prepared by dissolving $0.025 \mathrm{~g}$ of nitrazepam (NDI-Iraq) in $5 \mathrm{ml}$ of ethanol by heating and the volume is diluted to $25 \mathrm{ml}$ with ethanol in a volumetric flask, a 5 $\mathrm{ml}$ of this solution is taken and a $0.4 \mathrm{~g}$ of zinc powder, $2 \mathrm{ml}$ of $36 \%$ concentrated $\mathrm{HCl}$ are added then the reaction mixture is shaked occasionally for $30 \mathrm{~min}$. The solution is filtered and the filtrate is completed with distilled water to $50 \mathrm{ml}$ in a volumetric flask. This solution is stable for at least one week.

\section{Hydrochloric acid, $1 \mathrm{~N}$.}

This solution is prepared by appropriate dilution of $36 \%$ concentrated hydrochloric acid solution to $250 \mathrm{ml}$ with distilled water in a volumetric flask.

\section{Sodium nitrite solution, $\mathbf{0 . 5 \%}$.}

This solution is prepared by dissolving $0.5 \mathrm{~g}$ of sodium nitrite in $100 \mathrm{ml}$ distilled water in a volumetric flask.

\section{Sulphamic acid solution, $1 \%$.}

This solution is prepared by dissolving $1 \mathrm{~g}$ of sulphamic acid in $100 \mathrm{ml}$ distilled water in a volumetric flask.

\section{N-(1-naphthyl)ethylenediamine dihydrochloride (NEDA) reagent solution, $0.1 \%$.}

This solution is prepared by dissolving $0.1 \mathrm{~g}$ of (NEDA) in $100 \mathrm{ml}$ distilled water in a volumetric flask.

\section{Procedure and calibration graph}

To a series of $25 \mathrm{ml}$ calibrated flasks, an increasing volume covering the concentration range $(1-500) \mu \mathrm{g} .25 \mathrm{ml}^{-1}$ of reducing form of nitrazepam solution are transferred, followed by the addition of $1 \mathrm{ml}$ of $1 \mathrm{~N}$ of hydrochloric acid and $1 \mathrm{ml}$ of $0.5 \%$ sodium nitrite solution and, shaking occasionally for $3 \mathrm{~min}$, then a $3 \mathrm{ml}$ of $1 \%$ sulphamic acid is added, with occasional shaking and standing for $3 \mathrm{~min}$. to remove the excess of nitrite ions, a $2.5 \mathrm{ml}$ of $0.1 \%$ (NEDA) reagent is added and the flasks are diluted with distilled water. The absorbances are measured at $564 \mathrm{~nm}$ against the reagent blank. Beer's law is obeyed over the range of concentration 1 to $200 \mu \mathrm{g}$ nitrazepam in $25 \mathrm{ml}$ and a concentration above 200 $\mu \mathrm{g}$ in $25 \mathrm{ml}$ gives a negative deviation (Fig. 1). The apparent molar absorptivity referred to nitrazepam has been found to be $1.633 \times 10^{3} 1 . \mathrm{mol}^{-1} . \mathrm{cm}^{-1}$. 


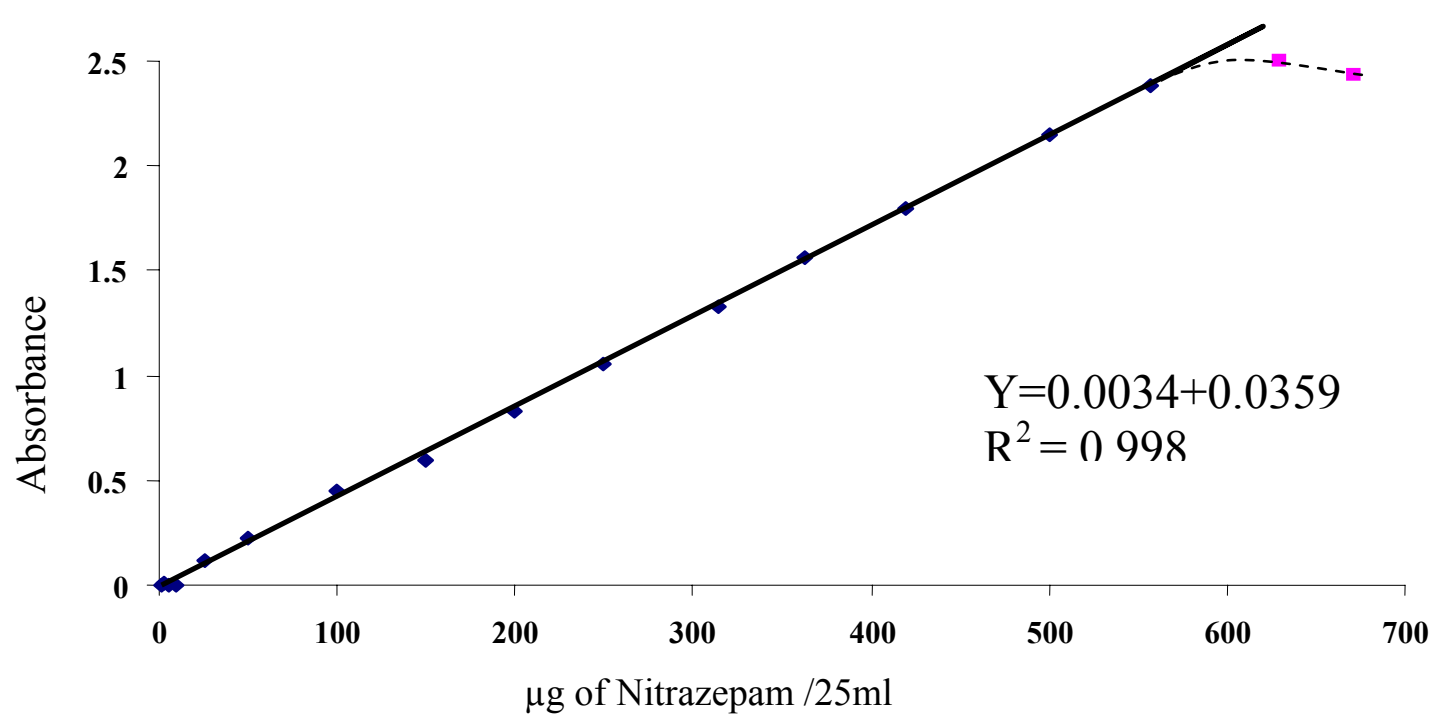

Fig. 1. Calibration graph for Nitrazepam determination

\section{RESULTS AND DISCUSSION}

During the investigation, $100 \mu \mathrm{g}$ of reducing nitrazepam is taken and the final volumes are brought to $25 \mathrm{ml}$ with distilled water.

\section{Optimization of variables}

The effect of various parameters on the absorption intensity of the colored complex is studied and the reaction conditions have been optimized.

\section{Effect of quality and quantity of acid used for diazotization reaction}

The effect of quality and quantity of acid on intensity of the coloured complex is examined. Different volumes (0.5-7.0) $\mathrm{ml}$ of $1 \mathrm{~N}$ of different acid solutions are added to an aliquot of solution containing $100 \mu \mathrm{g}$ of reducing form of nitrazepam. The intensities of absorption are read against the reagent blank. The results are shown in Table 1.

Table 1: Effect of quality and quantity of acid.

\begin{tabular}{|c|c|c|c|c|c|c|c|c|c|c|}
\hline \multirow{2}{*}{$\begin{array}{c}\text { Acid } \\
\mathbf{1 N}\end{array}$} & \multicolumn{10}{|c|}{ Absorbance / ml of acid } \\
\cline { 2 - 13 } & $\mathbf{0 . 5}$ & $\mathbf{1 . 0}$ & $\mathbf{1 . 5}$ & $\mathbf{2 . 0}$ & $\mathbf{2 . 5}$ & $\mathbf{3 . 0}$ & $\mathbf{4 . 0}$ & $\mathbf{5 . 0}$ & $\mathbf{6 . 0}$ & $\mathbf{7 . 0}$ \\
\hline $\mathbf{H C l}$ & 0.548 & 0.552 & 0.532 & 0.530 & 0.498 & 0.481 & 0.476 & 0.461 & 0.457 & 0.462 \\
\hline $\mathbf{H}_{\mathbf{2}} \mathbf{S O}_{\mathbf{4}}$ & 0.527 & 0.537 & 0.530 & 0.525 & 0.537 & 0.535 & 0.521 & 0.505 & 0.510 & 0.505 \\
\hline $\mathbf{H N O}_{\mathbf{3}}$ & 0.491 & 0.497 & 0.506 & 0.501 & 0.504 & 0.494 & 0.481 & 0.453 & 0.434 & 0.440 \\
\hline $\mathbf{C H}_{\mathbf{3}} \mathbf{C O O H}$ & 0.509 & 0.518 & 0.522 & 0.532 & 0.520 & 0.527 & 0.533 & 0.541 & 0.521 & 0.527 \\
\hline $\mathbf{H C O O H}$ & 0.500 & 0.512 & 0.502 & 0.501 & 0.492 & 0.469 & 0.469 & 0.444 & 0.456 & 0.462 \\
\hline $\mathbf{H}_{\mathbf{3}} \mathbf{P O}_{\mathbf{4}}$ & 0.531 & 0.538 & 0.533 & 0.529 & 0.527 & 0.521 & 0.517 & 0.507 & 0.501 & 0.449 \\
\hline $\mathbf{H C l O}_{\mathbf{4}}$ & 0.528 & 0.539 & 0.537 & 0.535 & 0.537 & 0.501 & 0.497 & 0.497 & 0.469 & 0.471 \\
\hline
\end{tabular}


The results shown in Table 1 indicate that $1.0 \mathrm{ml}$ of $1 \mathrm{~N} \mathrm{HCl}$ is considered as an optimum value therefore it is recommended for subsequent experiments.

\section{Effect of sodium nitrite amount with the time}

Different amounts of the $0.5 \% \mathrm{NaNO} 2$ solution are added and the time needed to complete the diazotization of reducing form of nitrazepam is studied by standing of the solutions after adding sodium nitrite solution for different times, with occasional shaking, then the other reagents are added and the absorbance is measured against the reagent blank .The results indicate that complete diazotization of nitrazepam occurs after $3 \mathrm{~min}$. when 1 $\mathrm{ml}$ of $0.5 \% \mathrm{NaNO}_{2}$ solution is added because it gives the higher sensitivity, therefore it has been selected for subsequent experiments.

\section{Effect of sulphamic acid amount with the time}

The effect of the amount of $1 \%$ sulphamic acid solution for removing the excess sodium nitrite with the standing time with occasional shaking are investigated. The results indicate that complete reaction of sulphamic acid with sodium nitrite occurs after 3 min. when $3 \mathrm{ml}$ of $1 \%$ sulphamic acid solution are added and the intensity decreased above 3 min. because the intensity of reagent blank increased. Therefore, the standing time $3 \mathrm{~min}$. is recommended for the subsequent experiments.

\section{Effect of the (NEDA) reagent amount}

The effect of the amount of $0.1 \%$ (NEDA) reagent on a maximum formation of the coloured complex is investigated. The results are shown in Table 2.

Table 2: Effect of the amount of (NEDA) reagent amount on absorbance.

\begin{tabular}{|c|c|c|c|c|c|c|c|}
\hline \multirow{2}{*}{$\begin{array}{c}\text { ml of } 1 \% \\
\text { N-NED }\end{array}$} & \multicolumn{6}{|c|}{ Absorbance of nitrazepam $\mu \mathrm{g} / \mathrm{ml}$} & \multirow[t]{2}{*}{$\mathbf{R}$} \\
\hline & & 10 & 25 & 50 & 100 & 200 & \\
\hline \multirow{2}{*}{0.5} & B & \multicolumn{5}{|c|}{0.006} & \multirow{2}{*}{0.999413} \\
\hline & $\mathbf{S}$ & 0.061 & 0.118 & 0.232 & 0.434 & 0.909 & \\
\hline \multirow{2}{*}{1.0} & B & \multicolumn{5}{|c|}{0.007} & \multirow{2}{*}{0.998425} \\
\hline & $\mathbf{S}$ & 0.063 & 0.119 & 0.245 & 0.487 & 1.075 & \\
\hline \multirow{2}{*}{1.5} & B & \multicolumn{5}{|c|}{0.008} & \multirow{2}{*}{0.999666} \\
\hline & $\mathbf{S}$ & 0.061 & 0.117 & 0.234 & 0.498 & 1.058 & \\
\hline \multirow{2}{*}{2.0} & B & & & 0.006 & & & \multirow{2}{*}{0.999393} \\
\hline & $\mathbf{S}$ & 0.062 & 0.155 & 0.267 & 0.532 & 1.112 & \\
\hline \multirow{2}{*}{2.5} & B & & & 0.008 & & & \multirow{2}{*}{0.999924} \\
\hline & $\mathbf{S}$ & 0.065 & 0.153 & 0.278 & 0.565 & 1.126 & \\
\hline \multirow{2}{*}{3.0} & B & & & .008 & & & \multirow{2}{*}{0.999666} \\
\hline & $\mathbf{S}$ & 0.064 & 0.149 & 0.262 & 0.546 & 1.123 & \\
\hline
\end{tabular}


The results shown in Table 2 indicated that $2.5 \mathrm{ml}$ of (NEDA) reagent solution give the higher sensitivity value of correlation coefficient, therefore it has been selected for the subsequent experiments.

\section{Effect of acidity}

The effect of two different amount of $1 \mathrm{~N} \mathrm{HCl}$ on intensity of the coloured complex formed when added to an aliquot of solution containing $100 \mu \mathrm{g}$ of reducing form of nitrazepam is examined. The intensities of absorption are read against the reagent blank. The results are shown in Table 3.

Table 3: Effect of the acidity on absorbance.

\begin{tabular}{|c|c|c|}
\hline $\begin{array}{c}\text { With out addition of HCl } \\
\text { After N-NED }\end{array}$ & $\begin{array}{c}\mathbf{1} \text { ml of 1N HCl is added } \\
\text { after addition N-NED. }\end{array}$ & $\begin{array}{c}\mathbf{2} \text { ml of 1N HCl is added } \\
\text { after addition N-NED }\end{array}$ \\
\hline 0.558 & 0.554 & 0.556 \\
\hline
\end{tabular}

The results shown in Table 3 indicate that the addition of the acid after the formation of coloured complex does not increase the intensity of absorption of sample, therefore, the addition of an acid is not selected for subsequent investigation.

\section{Effect of surfactants}

The effect of surfactants were studied by the addition of $3 \mathrm{ml}$ of various types of surfactant (cationic, anionic and neutral) to the medium of reaction with different orders of addition. The results are shown in Table 4 . The selected surfactants are :

Cetylpyridinium chloride monohydride (CPC), (cationic).

Sodium dodecyl sulphate (SDS), (anionic).

Polyoxyethylene (20) (Tween 80), (neutral).

Table 4: Effect of surfactants and the order of addition.

\begin{tabular}{|c|c|c|c|c|c|c|c|c|c|c|}
\hline \multirow{2}{*}{$\begin{array}{c}\text { Surfactant } \\
\text { type }\end{array}$} & \multicolumn{2}{|c|}{ I } & II & \multicolumn{3}{c|}{ III } & \multicolumn{3}{c|}{ IV } & \multicolumn{3}{c|}{ V } \\
\cline { 2 - 10 } & $\mathrm{A}$ & $\lambda_{\max }$ & $\mathrm{A}$ & $\lambda_{\max }$ & $\mathrm{A}$ & $\lambda_{\max }$ & $\mathrm{A}$ & $\lambda_{\max }$ & $\mathrm{A}$ & $\lambda_{\max }$ \\
\hline $\begin{array}{c}\mathrm{CPC} \\
1 \times 10^{-3} \mathrm{M}\end{array}$ & 0.558 & 564 & 0.556 & 564 & 0.478 & 550 & 0.554 & 565 & 0.551 & 560 \\
\hline $\begin{array}{c}\mathrm{SDS} \\
1 \times 10^{-3} \mathrm{M}\end{array}$ & 0.553 & 565 & 0.549 & 564 & 0.561 & 567 & 0.552 & 571 & 0.553 & 571 \\
\hline $\begin{array}{c}\text { Tween } 80 \\
1 \times 10^{-3} \mathrm{M}\end{array}$ & 0.491 & 581 & ----- & ----- & 0.481 & 581 & 0.515 & 562 & 0.441 & 561 \\
\hline
\end{tabular}

- $\quad$ absorbance without surfactant $=0.565$

I: Sample + Surfactant $+\mathrm{HCl}+\mathrm{NaNO}_{2}+$ Sulphamic acid + Reagent (NEDA).

II: Sample $+\mathrm{HCl}+$ Surfactant $+\mathrm{NaNO}_{2}+$ Sulphamic acid + NEDA.

III: Sample $+\mathrm{HCl}+\mathrm{NaNO}_{2}+$ Surfactant + Sulphamic acid + NEDA.

IV: Sample $+\mathrm{HCl}+\mathrm{NaNO}_{2}+$ Sulphamic acid + Surfactant + NEDA.

V: Sample $+\mathrm{HCl}+\mathrm{NaNO}_{2}+$ Sulphamic acid + NEDA + Surfactant.

VI: Sample $+\mathrm{HCl}+\mathrm{NaNO}_{2}+$ Sulphamic acid $+\mathrm{NEDA}\left(\mathrm{A}=0.0554\right.$ and $\left.\lambda_{\max }=564\right)$. 
The results in Table 4 indicate that there is no change in the intensity of coloured product. Therefore, surfactants have been omitted in the subsequent experiments.

\section{Effect of time}

The effect of time on the development and stability of the colored complex for different amounts of reducing form of nitrazepam is investigated under the optimum experimental conditions is established. Complete color formation occurs immediately after all reaction mixture are added and the absorbance of the complex remains constant for at least 60 minutes (Table 5).

Table 5: Effect of time on the absorbance of complex.

\begin{tabular}{|c|c|c|c|c|c|c|c|c|}
\hline \multirow{2}{*}{$\begin{array}{c}\mu \mathrm{g} \text { of } \\
\text { [nitrazepum } \\
\text { per } 25 \mathrm{ml}]\end{array}$} & \multicolumn{8}{|c|}{ Absorbance / min } \\
\hline & $\begin{array}{c}\text { Direct } \\
\text { addition }\end{array}$ & 5 & 10 & 20 & 30 & 40 & 50 & 60 \\
\hline 5 & 0.023 & 0.039 & 0.041 & 0.041 & 0.040 & 0.040 & 0.041 & 0.041 \\
\hline 50 & 0.197 & 0.268 & 0.271 & 0.272 & 0.272 & 0.271 & 0.272 & 0.273 \\
\hline 100 & 0.210 & 0.469 & 0.529 & 0.556 & 0.556 & 0.555 & 0.557 & 0.556 \\
\hline 200 & 0.439 & 0.989 & 1.098 & 1.120 & 1.121 & 1.122 & 1.122 & 1.122 \\
\hline
\end{tabular}

\section{Absorption spectra}

Absorption spectra of the coloured complex formed from the reaction between diazotized reducing form of nitrazepam and (NEDA) reagent in acidic medium against its corresponding reagent blank shows maximum absorption at $564 \mathrm{~nm}$ in contrast to the (NEDA) reagent blank which have less absorption at $564 \mathrm{~nm}$ (Fig.2). 


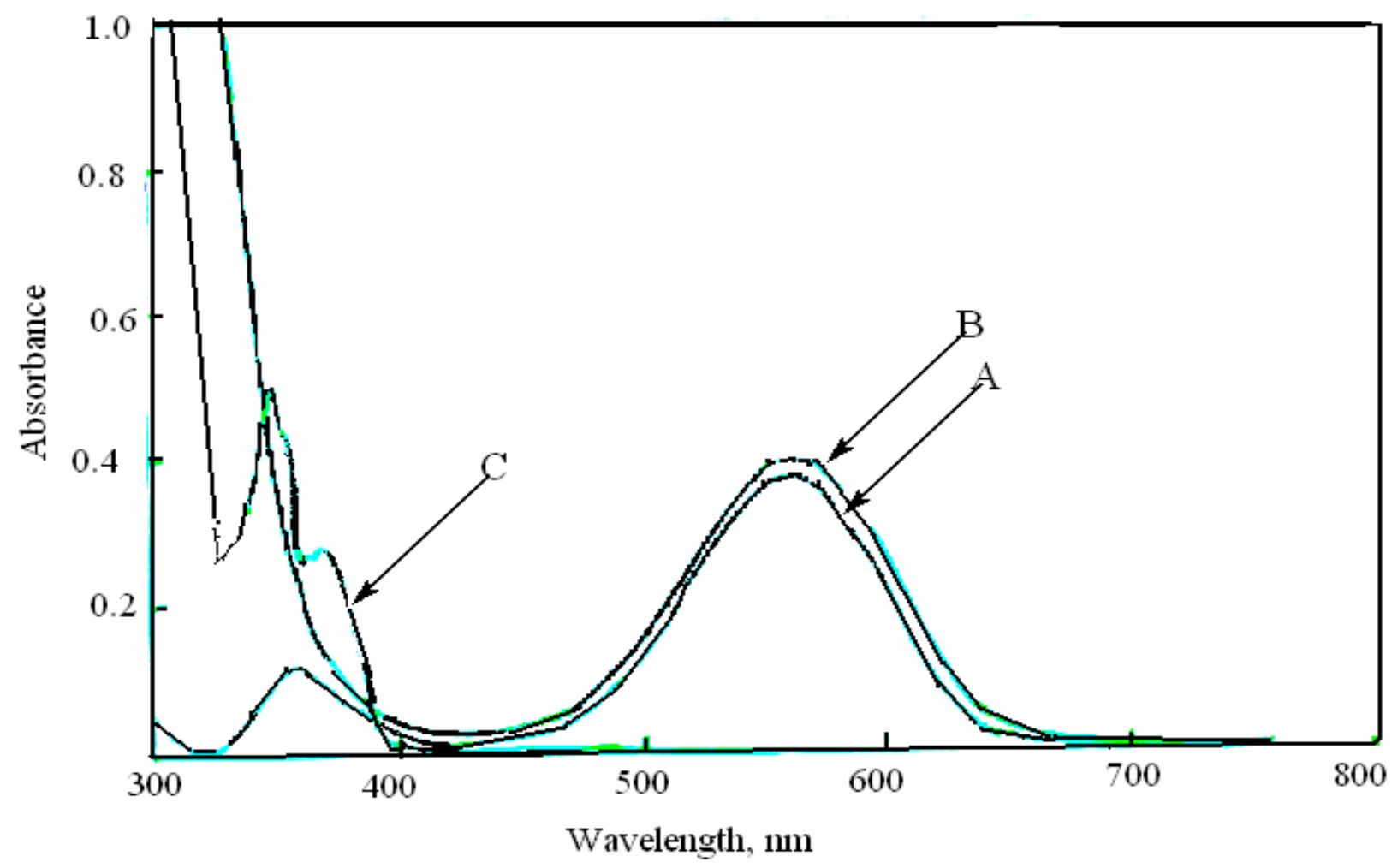

Fig. 2: Absorption spectra of $100 \mu \mathrm{g}$ of reducing form of nitrazepam / $25 \mathrm{ml}$ treated according to the optimum conditions and measured against (A) blank, (B) distilled water, and (C) blank measured against distilled water.

\section{Accuracy and precision}

To check the accuracy and precision of the calibration graph, nitrazepam is determined at three different concentrations. The results shown in Table 6 indicated that the calibration graph is satisfactory.

Table 6: Accuracy and precision.

\begin{tabular}{|c|c|c|}
\hline $\begin{array}{c}\text { Amount of nitrazepam } \\
\text { taken, } \boldsymbol{\mu g} / \mathbf{2 5 m l}\end{array}$ & Relative error*, $\%$ & $\begin{array}{c}\text { Relative standard } \\
\text { deviation* } \%\end{array}$ \\
\hline 10 & -2.45 & 1.07 \\
\hline 25 & +0.67 & 1.00 \\
\hline 50 & -0.72 & 1.00 \\
\hline
\end{tabular}

* Average of five determinations.

\section{Nature of nitrazepam-(NEDA) reagent complex.}

Job's method (Delevie, 1997) and mole ratio method have been used in the determination of the reaction ratio of nitrazepam with (NEDA) reagent. The obtained results (Fig.3 \& Fig.4) showed that 1:1 nitrazepam to (NEDA) reagent ratio is obtained. 


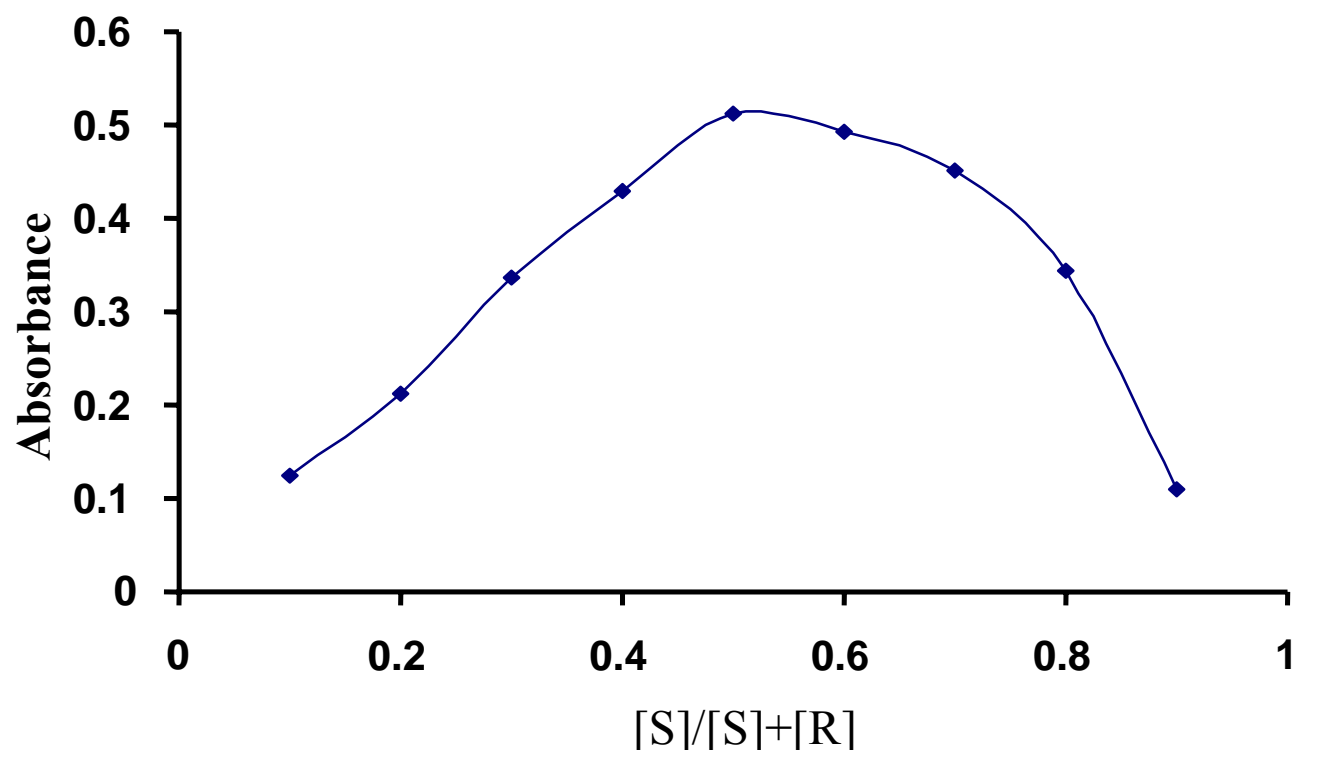

Fig. 3: Job's plot for nitrazepam (NEDA) reagent.

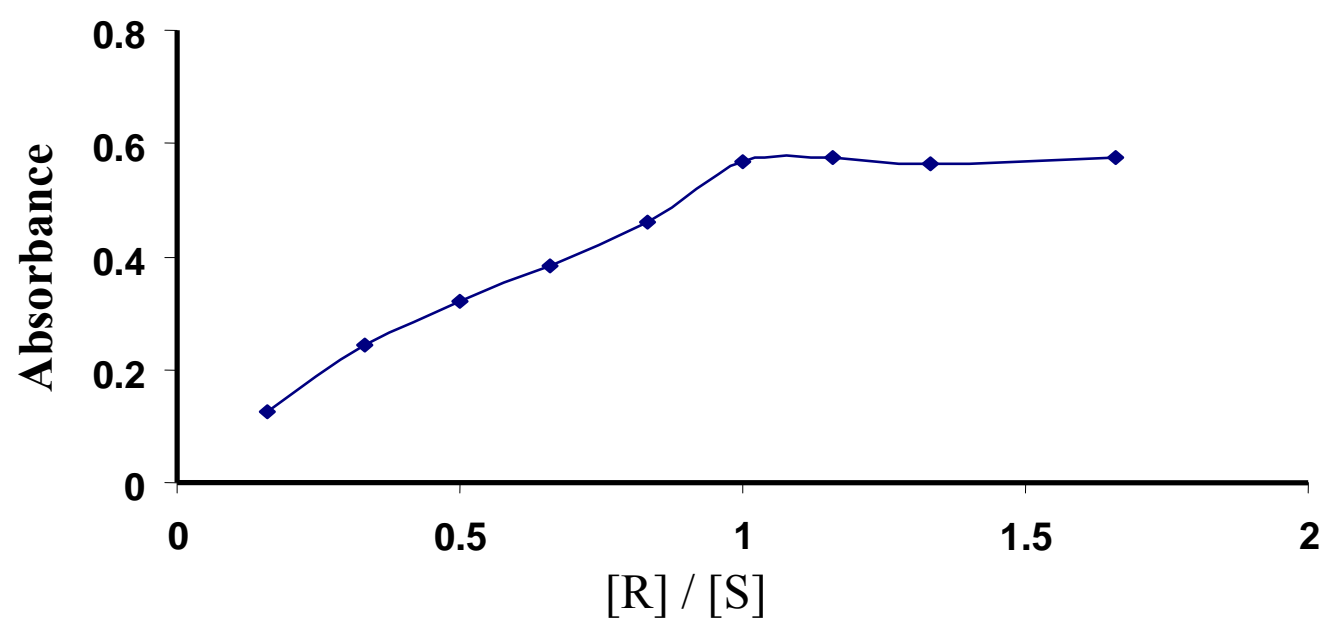

Fig. 4: Mole ratio's plot for nitrazepam-(NEDA) reagent complex. 
From the above resulting data the probable azo dye formation is shown as follow:<smiles>Nc1ccc2c(c1)C(c1ccccc1)=NCC(=O)N2</smiles><smiles>N#[N+][C-]1C(c2ccccc2)=NCC(=O)Nc2ccccc21</smiles>

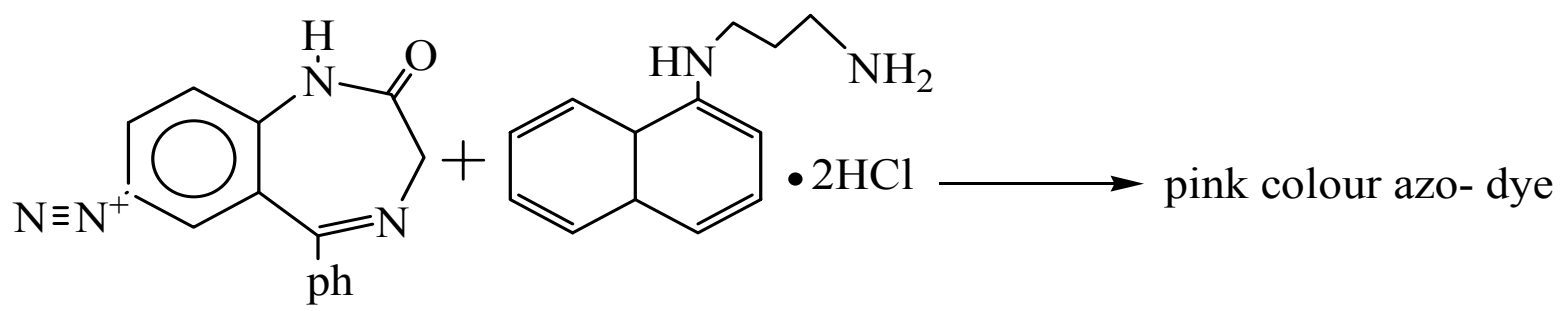

Stability constant of formed dye (Haris, 1998)

Stability constant of formed dye is calculated with ratio $1: 1$. The results are shown in which Table 7, indicate that the average of stability constant is $4.348 \times 10^{3} 1 . \mathrm{mol}^{-1}$, indicating that the coloured complex is stable.

Table 7: Stability constant of formed dye.

\begin{tabular}{|c|c|c|c|c|}
\hline \multirow{2}{*}{$\begin{array}{c}\text { ml of nitrazepam } \\
\mathbf{3 . 5 5 5} \times \mathbf{1 0}^{-\mathbf{4}} \mathbf{M}\end{array}$} & \multicolumn{3}{|c|}{ Absorbance } & \multirow{2}{*}{ K.M $^{\mathbf{1}}$} \\
\cline { 2 - 4 } & $\mathbf{A s}$ & $\mathbf{A m}$ & $\boldsymbol{\alpha}$ & \\
\hline 1 & 0.099 & 0.219 & 0.548 & $4.233 \times 10^{3}$ \\
\hline 2.5 & 0.433 & 0.939 & 0.539 & $4.463 \times 10^{3}$ \\
\hline
\end{tabular}

\section{Interference of foreign species}

The effect of various species on the determination of nitrazepam is investigated. The results are shown in Table 8. 
Table 8: Effect of interferences on the determination of nitrazepam.

\begin{tabular}{|c|c|c|c|c|}
\hline \multirow{2}{*}{ Interference } & \multicolumn{3}{|c|}{ Recovery(\%) of $\mathbf{1 0 0} \boldsymbol{\mu g}$ nitrazepam / $\boldsymbol{\mu g}$ of foreign compound added } \\
\cline { 2 - 5 } & $\mathbf{5 0}$ & $\mathbf{1 0 0}$ & $\mathbf{3 0 0}$ & $\mathbf{5 0 0}$ \\
\hline Starch & 101.04 & 101.73 & 101.21 & 101.56 \\
\hline Glucose & 101.91 & 98.78 & 99.65 & 99.82 \\
\hline Acacia & 100.69 & 100.52 & 98.78 & 101.56 \\
\hline Glycerol & 101.04 & 97.39 & 100.69 & 100.86 \\
\hline Dextrose & 101.04 & 99.30 & 98.26 & 100.34 \\
\hline Lactose & 100.69 & 98.78 & 98.26 & 100.86 \\
\hline Sucrose & 97.04 & 101.04 & 100.86 & 100.21 \\
\hline
\end{tabular}

\section{Application of the method}

The proposed method was successfully applied to the determination of nitrazepam in its pharmaceutical preparations. The results which are shown in Table 9 indicate that a good recovery was obtained.

Table 9: Analytical applications.

\begin{tabular}{|c|c|c|c|}
\hline \multirow{2}{*}{$\begin{array}{c}\text { Nitrazepam } \\
\text { amount, } \boldsymbol{\mu g}\end{array}$} & $\begin{array}{c}\text { Absorbance of standard } \\
\text { solution }\end{array}$ & \multicolumn{2}{|c|}{$\begin{array}{c}\text { Morgan (mg/ tablet) } \\
\text {-syria }\end{array}$} \\
\cline { 3 - 4 } & & Absorbance & Recovery(\%) \\
\hline 25 & 0.121 & 0.115 & 95.04 \\
\hline 50 & 0.224 & 0.219 & 97.76 \\
\hline 100 & 0.452 & 0.461 & 101.99 \\
\hline 200 & 0.829 & 0.833 & 100.48 \\
\hline
\end{tabular}

\section{Comparison of the methods}

Table 10 shows the comparison between some of analytical variables obtained from the present method with that of the recent spectrophotometric method.

Table 10: Comparison of methods.

\begin{tabular}{|c|c|c|}
\hline Analytical parameters & Present method & $\begin{array}{l}\text { Literature method (Al- } \\
\text { Gabsha.et al,2008) }\end{array}$ \\
\hline Medium reaction & Acidic & Neutral \\
\hline Temperature $\left(\mathrm{C}^{\circ}\right)$ & Room temperature & Room temperature \\
\hline Development time (minutes) & Direct measuring & Direct measuring \\
\hline$\lambda \max (\mathrm{nm})$ & 564 & 485 \\
\hline Reagent coupling & $\begin{array}{l}\text { N-(1-naphthyl) ethylene- } \\
\text { diaminehydrochloric acid }\end{array}$ & Resorcinol \\
\hline Beer's law range (ppm) & $0.04-8.0$ & $0.4-8.0$ \\
\hline Molar absorbtivity $\left(1 . \mathrm{mol}^{-1} \cdot \mathrm{cm}^{-1}\right)$ & $1.633 \times 10^{3}$ & 14900 \\
\hline RSD (\%) & 1.07 & $>\% \pm 3.47$ \\
\hline Color of the dye & Pink & Orang-yellowish \\
\hline Application of method & $\begin{array}{l}\text { Determination of nitrazepam } \\
\text { in tublets }\end{array}$ & $\begin{array}{l}\text { Determination of nitrazepam in } \\
\text { tablets }\end{array}$ \\
\hline
\end{tabular}




\section{CONCLUSION}

A simple, rapid, accurate and precise spectrophotometric method is evaluated for the determination of nitrazepam in pure form. The method is based on diazotization-coupling reaction between reduced product of nitrazepam and $\mathrm{N}$-(1-naphthyl) ethylenediaminedihydrochloride in acidic medium to produce a pink colour which is stable, water soluble and has a maximum absorption at $546 \mathrm{~nm}$ with a molar absorpitivity of $1.633 \times 10^{3} 1 . \mathrm{mol}^{-1} \cdot \mathrm{cm}^{-1}$. Beer's law is obeyed in the concentration range from $0.4-20 \mu \mathrm{g} / \mathrm{ml}$ of reduced form of nitrazepam. The proposed method has been applied successfully to the assay of nitrazepam with, out interferences.

\section{REFERENCES}

Al-Ghabsha, T.; Azoz, A. S.; Namir, A. (2008). Spectrophotometric method for determination of nitrazepam by using resorcinol as coupling agent, J. Edu. Sci., 21(1), 147-163.

British Pharmacopoeia 3rd edn., CDROM, (2000). System Simulation Ltd, Stationary Office, London.

Carmona, M.; Silva, M.; Perez-Bendito, D. (1992). Kinetic determination of nitrazepam in tablets, Anal. Lett., 25(7), 1261-1274.

Davidson, A. G.; Lia, H. W. (2005). Spectrophotometric determination of nitrazepam in drug dosage forms, J. Pharm. Pharmacol, 41(60), 63-65.

Delvie, R. (1997). "Principles of Quantitative Chemical Analysis", International Edn., McGraw-Hill Inc., Singapore, 498 p.

El-Brashy, A.; Aly, F. A; Belal, F. (1993). Determination of 1,4-bezodiazepines in drug dosage forms by difference sepectrophotometry, Mikrochim. Acta, 110, 55-60.

Haris, L.G. (1988). "Analytical Chemistry" , Prentice Hall, 1nc., New Jersey, USA, 427 p.

Honeychurch, K. C.; Smith, G.C; Hart, J.P. (2006). Voltammetric behavior of nitrazepam and its determination in serum using liquid chromatography with redox mode duelelectrode detection, Anal.Chem., 78(2), 416-423.

Inoue, T. (1985). Nitrazepam and its main metabolites in urine by thin-layer chromatography and direct densitometry, Chromatog., 339(1), 163-169.

Katzunag, B.G. (1998). "Basic and Clinical Pharmacology", The McGraw Hill, Inc.University of California, USA, 11th edn., pp.354-360.

Walash, M. I.; El-Brashy, A. M.; Sultan, M. A. (1993). Colorimetric determination of some aromatic nitro compounds of pharmaceutical interest, Analy. Lett., 26(3), 499-512.

Yokchue, T.; Wongchanapai, W. (2010). Analysis of 15 bezodiazepines in blood by HPLC, Thesis Advisors, Mahidol University, pp.6-97. 